\title{
Short Communication: \\ Evaluation of antimicrobial activities of Alchemilla vulgaris and Portulaca oleracea ethanolic extracts and correlation with their phytochemical profiles
}

\author{
SALEM MOHAMED EDRAH \\ Department of Chemistry, Faculty of Arts and Sciences, Al-Mergeb University. Al-Khums, P.O. Box 40397/40414, Libya. Tel: +218-924748909, \\ email: drsalemedrah@gmail.com
}

Manuscript received: 12 June 2017. Revision accepted: 11 August 2017.

\begin{abstract}
Edrah SM. 2017. Short Communication: Evaluation of antimicrobial activities of Alchemilla vulgaris and Portulaca oleracea ethanolic extracts and correlation with their phytochemical profiles. Biofarmasi J Nat Prod Biochem 15: 91-94. The ethanol extracts of leaves of Alchemilla vulgaris and Portulaca oleracea were studied for antimicrobial activity at $10 \mathrm{mg} / \mathrm{mL}$ concentrations by using the disc diffusion method on two gram-positive bacteria: Staphylococcus aureus and Staphylococcus epidermidis; three gram-negative bacteria: Escherichia coli, Klebsiella pneumoniae, and Pseudomonas aeruginosa and one fungus: Candida albicans were used in the study. After incubation for $24 \mathrm{hrs}$, the zone of inhibition was compared with standard antibiotics Gentamycin (10 $\mu \mathrm{g} / \mathrm{disc})$ used as a positive control. The dose-dependent study concluded that the ethanol extract of A. vulgaris was more potential than the leaf extract of $P$. oleracea. Almost all of the chemical ingredients present in both ethanol extracts, such as tannins, flavonoids, and phenols, may be responsible for the antimicrobial activity.
\end{abstract}

Keywords: Alchemilla vulgaris, antimicrobial activity, disc diffusion method, Portulaca oleracea

\section{INTRODUCTION}

Plants are great sources of new harmless, biodegradable, and renewable medications. The use of plants is as healing representatives in addition to existing medicine. Medicinal plants play an influential role in public health, especially in developing countries. It is considered that the great utilization of plants in healing activity seems not to be managed to intoxicate. The price of drugs in use today is too high for the bulk of people in the community in third world countries. Therefore, the search for cheap sources of antimicrobial substances in nature becomes inevitable.

Alchemilla vulgaris $\mathrm{L}$. has different names in various ethnic groups; in Libya, it is known as "rejel alasad," while Portulaca oleracea L. is known as "bleabsha." The aerial parts of the A. vulgaris plant, a member of the family Rosaceae, are applied to heal inflammation, particularly to the intestinal and female reproductive tracts, including maintaining to stop minor bleeding and treat wounds. $A$. vulgaris is an herbaceous herb, and it is in Libyan folk; this medicine is applied to urinary diseases. Moreover, it is also used to treat ovarian infections in women as well as for the treatment of diarrhea and internal bleeding, to treat vaginal diseases, uterine and abdominal relaxations after childbirth, and repeated abortions. This plant is a favorite for a gynecologist and is also prescribed to treat obesity and diabetes. $P$. oleracea, a member of the family Portulacaceae, is a warm climate annual green herb; it was reported as a global remedy due to its various therapeutic uses (Iwu 1993; Lim and Quah 2007). It is broadly used to treat diarrhea in both humans and animals in China and has been established with anti-inflammatory effects by recent studies (Lee 2012; Abd El-Azime et al. 2014).

Intended for several years, the limitation of bacterial infections by Inhibiting microbial growth was a major advance concerning antimicrobial treatment. Such approved antimicrobial medications were regularly utilized for medical infectious illnesses of various ages. Nevertheless, in current ages, the random application of certain antimicrobials leads to increased bacteria resistance and influence. Consequently, natural antimicrobial agents are needed more by traditional people.

\section{MATERIALS AND METHODS}

\section{Preparation of the crude ethanol extracts}

Two traditional medicinal plants, viz., A. vulgaris and P. oleracea (leaves), were screened. The good leaves of the two plants were collected, washed with distilled water, dried, and powdered finely using a blender. $20 \mathrm{~g}$ of ground, air-dried material was shaken with $500 \mathrm{~mL}$ of ethyl alcohol $\left(\mathrm{EtOH} 96^{\circ}\right)(\mathrm{w} / \mathrm{v})$ separated at room temperature with stirring for 96 hours (150 cycles/ minute). The ethanol was evaporated to dryness after extraction using a rotary vacuum evaporator. The extract was weighed and dissolved in ethanol $(2 \mathrm{~mL})$ at a $200 \mathrm{mg} / \mathrm{mL}$ concentration and stored at $4^{\circ} \mathrm{C}$ for further experiments. 


\section{Phytochemical analysis}

The presence of the main class metabolites was determined along with the standard methods (Harborne 1973; Matos 1988 et al.; Trease and Evans 1989; Sofowora 1993; Memelink et al. 2001; Raaman 2006). Freshly prepared extracts were subjected to standard phytochemical analyses to find the presence of the phytoconstituents.

Test for alkaloids. $10 \mathrm{~mL}$ of the crude extract was added to $2-3 \mathrm{~mL}$ of $\mathrm{HCl}(10 \%)$. This acidic medium was heated in a water bath. It was added by a volume of $\mathrm{NH}_{4} \mathrm{OH}(10 \%)$ to obtain a medium with $\mathrm{pH}=9$, which was extracted with ethylic ether and then concentrated with a rotary evaporator. The residue will be added with $0.5 \mathrm{~mL}$ of $\mathrm{HCl}(2 \%)$ and divided into two equal parts. The first was treated with a few drops of Mayer's reagent and the second with Wagner's reagent. Observation: turbidity or precipitation.

Test for tannins. A few milligrams of crude extract were dissolved in $3-5 \mathrm{~mL}$ of distilled water, and $1 \%$ ferric chloride solution drops were added. A change in color to dark green, blue, black, or the formation of a precipitate indicated a positive reaction showing the presence of tannins.

Test of saponins. $10 \mathrm{~mL}$ of the aqueous solution was added to a little water and then stirred strongly. Persistent foam indicated the presence of saponins.

Test for steroids. $3 \mathrm{~mL}$ of extract was dissolved in 3 $\mathrm{mL}$ of chloroform and $3 \mathrm{~mL}$ of concentrated $\mathrm{H}_{2} \mathrm{SO}_{4}$. Formation of Bluish red to cherry color in chloroform layer showed the presence of steroids.

Test for phlobatannins. $5 \mathrm{~mL}$ of plant extract was treated with $5 \mathrm{~mL}$ of $1 \% \mathrm{HCl}$ and heated. Red color precipitate indicated the presence of Phlobatannins in the sample.

Test for terpenoids. $3 \mathrm{~mL}$ of plant extract, $5-6 \mathrm{~mL}$ of chloroform, and 8-9 mL of Conc. $\mathrm{H}_{2} \mathrm{SO}_{4}$ was mixed. A reddish-brown precipitate at the interface confirmed the presence of terpenoids.

Test for flavonoids. A few milligrams of extract were dissolved in 8- $10 \mathrm{~mL}$ of methanol. The mixture was filtered, and 3-5 drops of concentrated $\mathrm{HCl}$ and both $1 \mathrm{~cm}$ pieces of magnesium tape were added. A pink tint in the solution indicated a positive reaction.

Test for phenols. $10 \mathrm{~mL}$ of plant extract, when treated with a few drops of the $\mathrm{FeCl}_{3}$ solution, gave blue-green color, and it confirmed the presence of phenols.

Test for proteins. About $50 \mathrm{mg}$ of the extract was dissolved in $10 \mathrm{~mL}$ of distilled water and filtered through Whatman no. 1 filter paper, and the filtrate was subjected to test for proteins.

Biuret test: $5 \mathrm{~mL}$ of filtrate was treated with 3 drops of $2 \%$ copper sulfate solution. To this, 3-4 mL of ethanol was added, followed by the addition of potassium hydroxide pellets. The pink color in the ethanol layer indicated the presence of proteins.

Test for glycosides. $5 \mathrm{~mL}$ of plant extract, $4-5 \mathrm{~mL}$ $\mathrm{Fecl}_{3}(5 \%)$, and $4-5 \mathrm{~mL}$ of acetic acid were added, then a few drops of $\mathrm{H}_{2} \mathrm{SO}_{4}$ were added to the mixture. Greenish blue color indicates the presence of glycosides.
Antimicrobial assay. Two gram-positive bacteria: Staphylococcus aureus and Staphylococcus epidermidis; three gram-negative bacteria: Escherichia coli, Klebsiella pneumoniae, and Pseudomonas aeruginosa; and one fungus: Candida albicans were used in the study.

\section{Preparation of inoculum}

Stock cultures were maintained at $4^{\circ} \mathrm{C}$ on slopes of nutrient agar. Active cultures for experiments were performed by transferring a loopful of cells from the stock cultures to test tubes of Mueller-Hinton broth (MHB) for bacteria and Sabouraud dextrose broth (SDB) for fungi that were incubated without agitation for $24 \mathrm{~h}$ at $37^{\circ} \mathrm{C}$ and $25^{\circ} \mathrm{C}$ respectively. To $5 \mathrm{~mL}$ of $\mathrm{MHB}$ and $\mathrm{SDB}, 0.2 \mathrm{~mL}$ of culture was inoculated and incubated until it reached the turbidity equal to that of the standard $0.5 \mathrm{McF}$ arland solution at 600nm, equivalent to 106-108 CFU/mL (McFarland 1907).

\section{Disc diffusion method}

In vitro antimicrobial activity was screened using Mueller Hinton Agar (MHA). The MHA plates were prepared by pouring $15 \mathrm{~mL}$ of molten media into sterile Petri plates. The plates were allowed to solidify for 5-6 mins, $0.1 \%$ inoculum suspension was swabbed uniformly, and the inoculum was allowed to dry for 4-5 mins. The same procedure was conducted on the fungi using Sabouraud dextrose agar. The extract concentration of 10 $\mathrm{mg} / \mathrm{mL}, 50 \mu \mathrm{l} / \mathrm{disc}$, was loaded on $6 \mathrm{~mm}$ sterile individual discs. The loaded disc was placed on the surface of the medium and was allowed to diffuse for 3-4 min, and the plates were set aside for incubation at $37^{\circ} \mathrm{C}$ for $24 \mathrm{~h}$. The negative control was prepared using a respective solvent (10 $\mu \mathrm{l}$ of Ethanol). Gentamycin $(10 \mu \mathrm{g} /$ disc $)$ was used as a positive control. At the end of incubation, inhibition zones formed around the disc were measured in millimeters (Baur et al. 1966). Each antimicrobial assay was performed in triplicate.

\section{RESULTS AND DISCUSSION}

\section{Phytochemical analysis}

Phytochemical constituents such as alkaloids, flavonoids, tannins, phenols, saponins, and several other aromatic compounds are secondary metabolites of plants that function as a defense mechanism against many microorganisms, insects, and other herbivores. The phytochemical constituents of the selected plants were studied as reviewed in Table 1. Analysis of plant extracts revealed the presence of these components in both selected plants, which could be responsible for the observed antimicrobial property.

It is fundamental to study medicinal plants to improve the proper use of medicinal plants and affirm their potential as sources for new medicines. The therapeutic properties of medicinal plants are essentially due to the presence of numerous chemical substances of various components that result in secondary metabolite products (Lozoya et al. 1989; Meckes-Lozoya et al. 1990; Karthikeyan et al. 2009). As shown in Table 1, each chemical constituent, alkaloids, 
tannins, saponins, steroids, Phlobatanins, terpenoids, flavonoids, phenols, and glycosides, present in leaf extracts in both $A$. vulgaris and $P$. oleracea. Still, phlobatanins are not present in $P$. oleracea, and proteins are not present in both. Phlobatannins have the diuretic property (Awoyinka et al. 2007). Saponins remain a remarkable class of glycosides that own soapy properties and are active agents against fungi (Sadipo et al. 1991; Chung et al. 1998). The presence of phenol compounds makes the resistance to diseases in humans and plants. Tannins are similarly recognized as antimicrobial agents; additionally, it has the potential to prevent the development of microorganisms by precipitating microbial protein (Sadipo et al. 1991), as well as by inhibiting the growth of several Microorganisms such as bacteria and fungi. It also has physiological properties such as anti-parasitic, anti-secretolytic, and anti-phlogistic effects (Asquith and Butler 1986). Consequently, because of the good results of applications against human pathogens, these plants may preferably be used as medications.

\section{Antimicrobial activities}

The antimicrobial activity of ethanol extracts of leaves of A. vulgaris and P. oleracea against human pathogenic bacteria, Staphylococcus aureus, Staphylococcus epidermidis, Escherichia coli, Klebsiella pneumoniae, Pseudomonas aeruginosa, and fungi: Candida albicans, is measured by quantifying the zone of inhibition in disc diffusion method (Table 2). The organisms and zone of inhibition to the corresponding extracts are shown in Table 2. The Zones of inhibition range from $7-13 \mathrm{~mm}$ for leaves of both extracts against bacteria and are $11 \mathrm{~mm}$ and $15 \mathrm{~mm}$ against fungi, respectively. The ethanol leave extract of $P$. oleracea has higher inhibition zones, i.e., 13, 7, 8, 9, and $10 \mathrm{~mm}$, against E. coli, K. pneumonia, P. aeruginosa, $S$. aureus, S. epidermidis, respectively, and lower inhibition zone, i.e., $11 \mathrm{~mm}$, against $C$. albicans. At the same time, the ethanol leaf extract of $A$. vulgaris has low inhibition zones, i.e., 10, 9, 11, 7, and $12 \mathrm{~mm}$ against each of $E$. coli, K. pneumonia, P. aeruginosa, S. aureus, S. epidermidis, respectively, and highest inhibition zone, of $15 \mathrm{~mm}$ against fungi $C$. albicans.

Table 1. Phytochemical screening of Alchemilla vulgaris and Portulaca oleracea leaves extracts

\begin{tabular}{lcc}
\hline Phytochemicals & Alchemilla vulgaris & Portulaca oleracea \\
\hline Alkaloids & + & + \\
Tannin & + & + \\
Saponin & + & + \\
Steroids & + & + \\
Phlobatannins & + & - \\
Terpenoids & + & + \\
Flavonoid & + & + \\
Phenolics & + & + \\
Proteins & - & - \\
Glycoside & + & + \\
\hline
\end{tabular}

Note: $+=$ present, $-=$ not present
Table 2. Antimicrobial activities of Alchemilla vulgaris, Portulaca oleracea, and the positive control tested against microorganisms by disk diffusion method

\begin{tabular}{|c|c|c|c|}
\hline \multirow[t]{2}{*}{ Bacterial types and fungi } & \multicolumn{3}{|c|}{$\begin{array}{c}\text { Plants names and antibiotic } \\
\text { Mean diameter of growth inhibition } \\
\text { zone }(\mathrm{mm})\end{array}$} \\
\hline & $\begin{array}{c}\text { Alchemilla } \\
\text { vulgaris }\end{array}$ & $\begin{array}{c}\text { Portulaca } \\
\text { oleracea }\end{array}$ & $\begin{array}{c}\text { Positive control } \\
\text { Gentamicin }\end{array}$ \\
\hline$\overline{\text { Escherichia coli }}$ & 10 & 13 & 18 \\
\hline Klebsiella pneumonia & 9 & 7 & 22 \\
\hline Pseudomonas aeruginosa & 11 & 8 & 19 \\
\hline Staphylococcus aureus & 7 & 9 & 17 \\
\hline Streptococcus epidermidis & 12 & 10 & 21 \\
\hline Candida albicans & 15 & 11 & 19 \\
\hline
\end{tabular}

Naturally, medicinal plants contain numerous phytochemical ingredients, which are significantly required to limit the growth of microorganisms. A. vulgaris and $P$. oleracea are utilized by Libyans as medications for treating many diseases. In conclusion, this research concludes that these plants' leaf extracts have satisfying activity against each of S. aureus, S. epidermidis, E. coli, K. pneumoniae, $P$. aeruginosa, and $C$. albicans.

\section{REFERENCES}

Abd El-Azime AS, Hussein EM, Ashry OM. 2014. Synergistic effect of aqueous purslane (Portulaca oleracea) extract and fish oil on radiation-induced damage in rats. Intl J Radiat Biol 90 (12): 11841190 .

Asquith TN, Butler LG. 1986. Interaction of Condensed Tannins with Selected Proteins. Phytochemistry 25 (7): 1591-1593.

Awoyinka OA, Balogun IO, Ogunnowo AA. 2007. Phytochemical Screening and In Vitro Bioactivity Cnidoscolus aconitifolius (Euphorbiaceae). J Med Plants Res 1 (3): 063-065.

Baur AW, Kirby WM, Sherris JC, Turck M. 1966. Antibiotic susceptibility testing by a standard single disk method. Am J Clin Path; 45: 493-496.

Chung KT, Wong TY, Wei CI, Huang YW, Lin Y. 1998. Tannins and human health: a review. Crit Rev Food Sci Nutr 38(6): 421-464.

Harborne JB. 1973. Phytochemical Methods. Chapman and Hall Ltd., London.

Iwu M. 1993. Handbook of African Medicinal Plants, 2nd ed. CRC Press, Boca Raton.

Karthikeyan A, Shanthi V, Nagasathaya A. 2009. Preliminary phytochemical and antibacterial screening of crude extract of the leaf of Adhatoda. vasica. L. Intl J Green Pharm 3: 78-80.

Lee AS, Kim JS, Lee YJ, Kang DG, Lee HS. 2012. Anti-TNF-alpha activity of Portulaca oleracea in vascular endothelial cells. Intl J Mol Sci 5: 5628-5644.

Lim YY, Quah EPL. 2007. Antioxidant properties of different cultivars of Portulaca oleracea. Food Chem 103: 734-740.

Lozoya X, Navarro V, Arnason JT, Kourany E. 1989. Experimental evaluation of Mimosa tenuiflora (Willd.) Poir. (Tepeschohuite) I. Screening of the antimicrobial properties of bark extracts. Arch Invest Med (Mex) 20: 87-93. [Spanish]

Matos FJA. 1988. Introdução à Fitoquímica Experimental. 2nd ed. Edições UFC, Fortaleza.

McFarland J. 1907. Nephelometer: an instrument for estimating the number of bacteria in suspensions used for calculating the opsonic index and for vaccines. J Am Med Assoc 14: 1176-1178.

Meckes-Lozoya M, Lozoya X, González JL. 1990. Pharmacological properties in vitro of various extracts of Mimosa tenuiflora (tepescohuite). Arch Invest Med (Mex) 21 (2): 163-169. 
Memelink J, Verpoort R, Kigine JW. 2001. ORCAnization of jasmonateresponsive gene expression in alkaloid metabolism. Trends Plant Sci 6 (5): $212-219$

Raaman N. 2006. Phytochemical Techniques. New India Publishing Company, New Delhi.
Sadipo OA, Akanji MA, Kolawole FB, Odutuga AA. 1991. Saponin is the active antifungal principle in Garcinia kola, heckle seed. Biosci Res Commun 3: 171 .

Sofowora A. 1993. Medicinal Plants and Traditional Medicine in Africa. Spectrum Books Ltd., Ibadan, Nigeria.

Trease GE, Evans WC. 1989. Pharmacognosy. 11st ed. Bailliere Tindall, London. 